The Bangladesh Veterinarian (2011) 28(1) : 39 - 46

\title{
Estimation of heritability for growth traits of Red Chittagong cattle in a nucleus herd
}

\author{
M. A. Afroz, M. A. Hoque and A. K. F. H. Bhuiyan* \\ Department of Animal Breeding and Genetics, Faculty of Animal Husbandry, Bangladesh \\ Agricultural University, Mymensingh-2202, Bangladesh
}

\begin{abstract}
The present study was undertaken to estimate the heritability for growth traits in a nucleus herd of Red Chittagong cattle (RCC) using data from 2005 to 2010. The traits considered were birth weight, weight at three-month intervals from birth to 24 months, and pre-weaning and post-weaning growth rate. The mean pooled weight (mean \pm se) of 127 RCC calves from birth to 24 months at three month intervals were $14.7 \pm 0.2,29.3 \pm 6.1$, $42.6 \pm 9.2,55.0 \pm 12.4,66.2 \pm 15.5,74.5 \pm 16.0,86.1 \pm 23.5,98.8 \pm 24.8$ and $111.6 \pm 25.2 \mathrm{~kg}$, respectively. The pre- and post-weaning growth rates were $148.5 \pm 45.0$ and $116.6 \pm 56.5$ $\mathrm{g} /$ day, respectively. The pre-weaning growth rate was significantly $(\mathrm{P}<0.01)$ higher than post-weaning. For the estimation of heritability single trait animal models under Residual Maximum Likelihood (REML) analyses were done considering sex, parity, season and year of birth as fixed effect and animal's additive genetic as random effect. Estimates of heritability for weight at birth, 3, 6, 9, 12, 15, 18, 21 and 24 month of age were $0.48 \pm 0.04$, $0.49 \pm 0.06,0.50 \pm 0.08,0.47 \pm 0.06,0.50 \pm 0.08,0.50 \pm 0.33,0.44 \pm 0.14,0.50 \pm 0.11$ and $0.50 \pm$ 0.15 , respectively. Heritability estimates for pre- and post-weaning growth rate were $0.48 \pm$ 0.06 and $0.49 \pm 0.17$, respectively. This moderately high heritability of growth of RCC suggests that RCC selected for growth up to 24 months of age would show a quick response. (Bangl. vet. 2011. Vol. 28, No. 1, 39 - 46)
\end{abstract}

\section{Introduction}

Red Chittagong cattle (RCC) is considered a promising genetic resource in Bangladesh. It is a tropically adapted Bos indicus and suited to low-input range conditions. Furthermore, they are reputed to give birth every year, which is considered a unique characteristic of RCC (Habib et al., 2003). Indiscriminate crossbreeding along with poor management has pushed the breed to the verge of extinction (Bhuiyan et al., 2005). Therefore, data on phenotypic and genetic parameters of RCC are made available to provide guidelines in order to improve meat production of RCC in Bangladesh.

Fast growth rate is an important trait but farmers are more interested in dualpurpose breeds. The objectives of the study were: (a) to estimate heritability $\left(h^{2}\right)$ of growth of RCC at different ages and (b) to compare growth performance in respect to sex, parity of dam, season and year of birth.

* Corresponding author:- E-mail: bhuiyanbau@gmail.com 


\section{Materials and Methods}

Source of data and management of animals

The data were collected from the nucleus herd of Red Chittagong cattle maintained at the Bangladesh Agricultural University, Mymensingh from 2005 to 2010.

Feeding and management practices were more or less uniform throughout the year. However, there were slight differences in the seasonal availability of green grasses, changed feeding regime, high ambient temperature, heavy rainfall and diseases which might have lead to variation in performance among animals. The animals were fed cultivated fodder (Maize, Napier, Para, and German) $3.0 \mathrm{~kg} /$ animal (Fresh weight), Urea molasses straw (UMS) and rice straw along with concentrates 1 $\mathrm{kg}$ and $0.25 \mathrm{~kg} /$ animal, respectively. Regular vaccination against Foot and Mouth Disease (half yearly) and Anthrax (yearly) was given as per manufacturer's instruction and all animals were dewormed against common parasites with fenbendezole (Peraclear ${ }^{\circledR}$, Techno Drugs, Dhaka, Bangladesh) $5 \mathrm{mg} / \mathrm{Kg}$ body weight and ivermectin (Cevamec $1 \%{ }^{\circledR}$, Ceva Sante, France) $0.2 / \mathrm{kg}$ body weight.

Traits studied

Traits included were birth weight, body weight at three-month intervals from birth to 24 months of age, and pre-weaning and post-weaning growth rate.

\section{Statistical analyses}

Data were analysed using SPSS 2002 computer software to estimate simple means and standard errors (mean \pm se). For estimating heritability $\left(h^{2}\right)$ VCE 4.2.5 (Groeneveld, 1998) computer software was used. All analyses were done using a single trait animal model with REML procedure where animal's additive genetic effect was the only random factor, with sex of the animal, parity of mother, season of birth, year of birth as fixed factors.

The statistical model in matrix notation was :

$\mathrm{Y}=\mathrm{Xb}+\mathrm{Za}+\mathrm{Wc}_{\mathrm{c}}+\mathrm{c}$

Where,

$\mathrm{Y}=$ Vector of observation

$\mathrm{X}, \mathrm{Z}$ and $\mathrm{W}=$ Known incidence matrices associated with levels of $\mathrm{b}, \mathrm{a}, \mathrm{c}$ with $\mathrm{Y}$.

$\mathrm{b}=$ Unknown vector of fixed effects (sex of calf, parity of dam, year of birth and season of birth)

$\mathrm{a}=$ Unknown vector of breeding value.

$c=$ Unknown vector of permanent environmental effect.

$\mathrm{e}=$ Vector of residual effects. 
The pre-weaning growth rate was calculated from weight at birth and at nine months and the post-weaning growth rate was considered as after nine months. The statistical comparison was done by using SPSS 2002 for windows computer software.

\section{Results and Discussion}

Birth weight

The overall mean birth weight was $14.7 \pm 0.2 \mathrm{~kg}$ (se) (Table 1). Males had significantly higher birth weight $(15.4 \pm 0.3 \mathrm{~kg})$ than females $(14.1 \pm 0.3 \mathrm{~kg})(\mathrm{P}<0.05)$. Similarly, the birth weight of RCC calves according to parity, season of birth and year of birth are presented in Table 2, 3 and 4, respectively. Habib et al. (2003) reported birth weight of RCC male and female as $17.3 \pm 0.7$ and $16.0 \pm 0.7 \mathrm{~kg}$, respectively. Khan et al. (2000) found a higher overall birth weight $17.3 \pm 0.8 \mathrm{~kg}$ and $16.0 \pm 0.6 \mathrm{~kg}$ of RCC calves reared on-station (intensive) and on-farm (rural extensive) management, respectively. Alam et al. (2007) reported birth weights for RCC male and female $15.7 \pm$ 0.7 and $13.7 \pm 1.0 \mathrm{~kg}$, respectively. Rabeya et al. (2009) found male and female birth weights as $15.7 \pm 0.3$ and $13.9 \pm 0.3 \mathrm{~kg}$, respectively. Anantakrishnan and Lazarus (1953); Singh and Tyagi (1970); Alam et al. (2007); Rabeya et al. (2009) reported that the sex of calves significantly influenced birth weight.

Parity of dam, season of birth and year of birth showed no significant influence on birth weight. This agrees with the findings of Alam et al. (2007); Rabeya et al. (2009).

Table 1. Mean birth weight $(\mathrm{kg})$ of RC calves according to sex

\begin{tabular}{l|c|c}
\hline \multicolumn{1}{c|}{ Sex } & No. of observation & Mean \pm SE \\
\hline Male & 64 & $15.4^{\mathrm{a}} \pm 0.3$ \\
Female & 63 & $14.1^{\mathrm{b}} \pm 0.3$ \\
Pooled & 127 & $14.7 \pm 0.2$ \\
\hline
\end{tabular}

Means with different superscript in the same column differ significantly $(\mathrm{P}<0.05)$

Table 2. Mean with standard error (SE) of birth weight according to parity

\begin{tabular}{l|c|c}
\hline \multicolumn{1}{c|}{ Parity } & No. of observations & Mean \pm SE \\
\hline $1^{\text {st }}$ & 29 & $14.2 \pm 0.5$ \\
$2^{\text {nd }}$ & 24 & $14.8 \pm 0.5$ \\
$3^{\text {rd }}$ & 27 & $14.4 \pm 0.4$ \\
$4^{\text {th }}$ & 21 & $14.9 \pm 0.5$ \\
$5^{\text {th }}$ & 17 & $15.7 \pm 0.5$ \\
$6^{\text {th }}$ & 9 & $14.9 \pm 0.9$ \\
Pooled & 127 & $14.7 \pm 0.2$ \\
\hline
\end{tabular}


Table 3. Mean with standard error (SE) of birth weight according to season of birth

\begin{tabular}{l|c|c}
\hline \multicolumn{1}{c}{ Season } & No. of observations & Mean \pm SE \\
\hline Summer & 40 & $15.0 \pm 0.4$ \\
Rainy & 38 & $13.9 \pm 0.4$ \\
Winter & 49 & $15.1 \pm 0.3$ \\
\hline Total & 127 & $14.7 \pm 0.2$ \\
\hline
\end{tabular}

Table 4. Mean with standard error (SE) of birth weight according to year of birth

\begin{tabular}{ccc}
\hline Year of birth & No. of observations & Mean \pm SE \\
\hline 2005 & 13 & $13.6 \pm 0.6$ \\
2006 & 33 & $15.0 \pm 0.4$ \\
2007 & 24 & $15.0 \pm 0.4$ \\
2008 & 25 & $15.0 \pm 0.5$ \\
2009 & 24 & $14.3 \pm 0.6$ \\
2010 & 8 & $14.6 \pm 0.7$ \\
\hline Total & 127 & $14.7 \pm 0.2$ \\
\hline
\end{tabular}

Estimated heritability of birth weight in the present study is $0.5 \pm 0.0$. This result is close to the findings of Ahunu et al. (1997) and Padua and Silva (1996) as $0.5 \pm 0.1$ and $0.45 \pm 0.5$, respectively and the result of Das et al. (2003) in Sahiwal x Pabna and Friesian $\times$ Pabna with a pooled average heritability of $0.4 \pm 0.3$. As presented by Deb (2004), estimated heritabilities for Local, Friesian $x$ Local and Jersey $x$ Local cattle were $0.37,0.50$ and 0.49 , respectively, similar to the present findings.

Heritability of birth weight trait of different breeds has been estimated by Martinez et al., (2002); Akbulut et al. (2002); Mandal and Sachdeva (1999); Bittencourt et al. (1998); Magana and Segura (1998); Gutierrez et al. (1997); Padua and Silva (1996); Rege et al. (1992); Reynolds et al. (1991); Wakhungu et al. (1991); Verma and Lohar (1985). Estimated heritability ranged between 0.21 and 0.49. Estimated value in the present study was within this range.

Heritability of birth weight suggests that selection will be effective in increasing birth weight and therefore, more emphasis may be given in cattle improvement programmes. On the other hand, high heritability of birth weight may be due to small number of observations or erratic nature of birth weight observed within the RC calves because their dams faced environmental stress while screened them from the field to form the on-station nucleus herd.

Body weight up to 24 months of age at 3 month intervals

Heritability $\left(h^{2}\right)$ of body weight of Red Chittagong (RC) calves up to 24 months of age at 3 month intervals (Table 5) ranges between $0.4 \pm 0.1$ and $0.5 \pm 0.1$. This is 
moderate. The results are similar to the findings of Rabeya et al. (2009). Also, Martins et al. (2002); Shojo et al. (2005) and Martinez et al. (2006) reported lower heritability in birth, weaning and growth traits of beef breeds.

Table 5. Mean body weight $(\mathrm{kg})$ of RCC and heritability $\left(h^{2}\right)$ at different age groups

\begin{tabular}{lcccc}
\hline \multicolumn{1}{c|}{ Age group } & No. of observations & Mean \pm SE & Heritability (h2) \\
\hline 3 months & 89 & $29.3 \pm 6.1$ & $0.49 \pm 0.1$ \\
6 months & 86 & $42.6 \pm 9.2$ & $0.50 \pm 0.1$ \\
9 months & 73 & $55.0 \pm 12.4$ & $0.47 \pm 0.1$ \\
12 months & 44 & $66.2 \pm 15.5$ & $0.50 \pm 0.1$ \\
15 months & 36 & $74.5 \pm 16.0$ & $0.50 \pm 0.3$ \\
18 months & 36 & $86.1 \pm 23.5$ & $0.44 \pm 0.1$ \\
21 months & 30 & $98.8 \pm 24.8$ & $0.50 \pm 0.1$ \\
24 months & 22 & $111.6 \pm 25.2$ & $0.50 \pm 0.2$ \\
\hline
\end{tabular}

Effects of sex, parity of dam, season of birth and year of birth on body weight at different ages are in Table 6 and 7. Growth of RCC at different ages is close to that reported by Rabeya et al. (2009). There were no significant differences in weight due to sex, parity, season of birth and year of birth. But male animals showed slightly higher weight gain in every age group.

Table 6. Body weight (Mean \pm SE) of RCC at different ages in respect of sex of calves and parity of dam

\begin{tabular}{l|c|c|c|c|c|c|cc}
\hline \multirow{2}{*}{$\begin{array}{c}\text { Age } \\
\text { group }\end{array}$} & \multicolumn{7}{|c}{ Mean \pm SE } \\
\cline { 2 - 9 } & \multicolumn{7}{|c}{ Sex } & \multicolumn{4}{c}{ Parity } \\
\cline { 2 - 9 } & Male & Female & $1^{\text {st }}$ & $2^{\text {nd }}$ & $3^{\text {rd }}$ & $4^{\text {th }}$ & $5^{\text {th }}$ & $6^{\text {th }}$ \\
\hline 3 months & $29.9 \pm 0.8$ & $28.5 \pm 1.0$ & $28.9 \pm 1.2$ & $29.6 \pm 1.5$ & $26.7 \pm 1.5$ & $30.5 \pm 1.0$ & $30.4 \pm 1.7$ & $35.7 \pm 5.4$ \\
6 months & $43.2 \pm 1.4$ & $41.9 \pm 1.3$ & $42.8 \pm 2.2$ & $41.0 \pm 1.8$ & $38.9 \pm 2.5$ & $44.8 \pm 1.8$ & $43.8 \pm 1.7$ & $51.5 \pm 8.6$ \\
9 months & $55.6 \pm 2.1$ & $54.3 \pm 1.9$ & $53.7 \pm 2.6$ & $53.7 \pm 3.2$ & $58.1 \pm 3.9$ & $56.6 \pm 3.2$ & $54.9 \pm 3.0$ & $51.2 \pm 7.1$ \\
12 months & $64.0 \pm 3.3$ & $68.4 \pm 3.2$ & $65.6 \pm 4.6$ & $68.0 \pm 4.5$ & $75.0 \pm 9.3$ & $68.0 \pm 4.7$ & $63.0 \pm 5.9$ & $49.3 \pm 3.9$ \\
24 months & $118.8 \pm 7.5$ & $101.2 \pm 4.1$ & $107.3 \pm 1$ & $115.0 \pm 1$ & $112.8 \pm 1$ & $110.1 \pm 5.4$ & $95.0 \pm 7.4$ & $118.0 \pm 0.0$ \\
\hline
\end{tabular}

Pre and post weaning growth rate

RC calves are weaned at around 9 months of age. The mean pre- and postweaning growth rates were $148.5 \pm 45.0 \mathrm{~g} /$ day and $116.6 \pm 56.5 \mathrm{~g} /$ day, respectively. The heritability was estimated as $0.48 \pm 0.1$ and $0.49 \pm 0.2$ for pre- and post-weaning growth rate. The difference in the rate of growth before and after weaning was significant $(\mathrm{P}<0.001$; Table 8$)$. Rabeya et al. (2009) reported pre-weaning growth rate as 
170 g/day. Gutierrez et al. (1997) reported higher growth rate before than after weaning.

Table 7. Body weight (Mean $\pm \mathrm{SE}$ ) of RCC at different ages and season and year of birth

\begin{tabular}{l|c|c|c|c|c|c|c|c}
\hline \multirow{2}{*}{$\begin{array}{c}\text { Age group } \\
\text { (Body } \\
\text { weight) }\end{array}$} & \multicolumn{9}{|c}{ Seasons } & \multicolumn{9}{c}{ Mean \pm SE } \\
\cline { 2 - 9 } & Summer & Rainy & Winter & 2005 & 2006 & 2007 & 2008 & 2009 \\
\hline 3 month & $29.6 \pm 1.3$ & $28.2 \pm 1.0$ & $30.1 \pm 1.0$ & $22.8 \pm 1.2$ & $30.5 \pm 0.9$ & $29.9 \pm 1.0$ & $28.0 \pm 1.4$ & $34.3 \pm 2.4$ \\
6 month & $43.9 \pm 1.6$ & $41.5 \pm 2.0$ & $42.6 \pm 1.4$ & $31.5 \pm 1.6$ & $46.8 \pm 1.3$ & $43.9 \pm 1.5$ & $39.2 \pm 2.3$ & $45.6 \pm 3.1$ \\
9 month & $52.2 \pm 3.3$ & $53.3 \pm 1.9$ & $58.2 \pm 2.2$ & $47.3 \pm 2.0$ & $60.8 \pm 2.2$ & $57.6 \pm 2.2$ & $49.6 \pm 4.7$ & $54.6 \pm 3.9$ \\
12 month & $59.9 \pm 6.5$ & $67.6 \pm 5.5$ & $68.3 \pm 2.4$ & $69.8 \pm 3.4$ & $78.3 \pm 5.2$ & $71.2 \pm 3.7$ & $55.0 \pm 3.2$ & $56.5 \pm 1.5$ \\
24 month & $100.3 \pm 8.3$ & $120.8 \pm 10.9$ & $109.7 \pm 4.2$ & $129.3 \pm 16.0$ & $113.7 \pm 15.5$ & $103.7 \pm 6.2$ & $106.1 \pm 5.9$ & - \\
\hline
\end{tabular}

Table 8 . Mean growth rate (g/day) with standard error and heritability $\left(h^{2}\right)$ of preand post-weaning growth rate

\begin{tabular}{l|c|c|c}
\hline \multicolumn{1}{c|}{ Growth rate } & No. of observation & Mean \pm SE & Heritability \\
\hline Pre-weaning & 72 & $148.5^{\mathrm{a}} \pm 45.0$ & $0.48 \pm 0.1$ \\
Post-weaning & 30 & $116.6^{\mathrm{b}} \pm 56.5$ & $0.49 \pm 0.17$ \\
\hline
\end{tabular}

Means with different superscript in the same column differ highly significantly $(\mathrm{P}<0.001)$

\section{Conclusions}

In conclusion those traits of RCC had heritability of medium value and from the breeding point of view, additive gene action is playing a vital role for their expression. This phenomenon promises improvement in the next generation through selection. Therefore, individuals own performance may be of top indicator during selection and breeding program execution when estimates for $h^{2}$ are satisfactory. In this respect, an indigenous variety or type among others the RCC possesses potential genetic merit and may be exploited and optimized to its apex.

\section{Acknowledgements}

The authors would like to thank USDA for funding the Red Chittagong cattle project.

\section{References}

Ahunu BK, Arthur PP, Kissiedu HWA 1997: Genetic and phenotypic parameters for birth and weaning weights of purebred and crossbred N'Dama and West African Shorthorn Cattle. Livestock Production Science 51 165-171. 
Akbulut O, Bayram B, Tuzemen N, Aydin R 2002: Phenotypic and genetic parameter estimates of Brown Swiss calves for birth weight and some body measurements at birth. Journal of Faculty of Agriculture, Ataturk Universitesi 33 59-64.

Alam M, Bhuiyan AKFH, Ali A, Mamun A 2007: Genetic analysis of birth weight and milk production of RCC of Bangladesh. Bangladesh Journal of Animal Science 36 24-32.

Anantakrishnan CP, Lazarus AJ 1953: Observations on some Indian cattle for a study of birth weight of calves. Indian Journal of Dairy Science 6 23-26.

Bhuiyan AKFH, Shahjalal M, Islam M N, Rahman AKMA, Kewon JF, Van Vleck LD 2005: Characterization, conservation and improvement of Red Chittagong Cattle of Bangladesh. Bangladesh Agricultural University Research Progress 1633.

Bittencourt TCC, Berlin C, Pires A 1998: Evaluation of environmental and genetic parameters affecting birth and weaning weight in Friesian calves in Bahia state. Animal Breeding Abstracts 66296.

Das PK, Ali SZ, Islam ABMM, Roy BK 2003: A comparative study of productive and reproductive performance and estimates of heritability for economic traits in different genetic groups of cattle available at Baghabarighat Milk Pocket Area of Bangladesh. Online Journal of Biological Science 3 726-740.

Deb GK 2004: Estimation of genetic parameters for some quantitative traits in dairy cattle of Bangladesh. MS Thesis, Department of Animal Breeding \& Genetics, Faculty of Animal Husbandry, Bangladesh Agricultural University, Mymensingh.

Groeneveld E 1998: User's guide and reference manual version 1.1. Institute of Animal Husbandry and Animal Behaviour, Mariansee, Federal Agricultural Research Center, Germany.

Gutierrez JP, Canon J, Goyache F 1997: Estimation of direct and genetic parameters for preweaning traits in Asturiana de los Valles beef cattle breed through animal and sire models. Journal of Animal Breeding and Genetics 114 261-266.

Habib MA, Bhuiyan AKFH, Bhuiyan MSA, Khan AA 2003: Performance of Red Chittagong Cattle in Bangladesh Agricultural University Dairy Farm. Bangladesh Journal of Animal Science 32 101-108.

Khan MKI, Haque KS, Mian AG, Khatun MJ 2000: Study on the performance of Red Chittagong cows under different production system. Pakistan Journal of Biological Science 3 318-319.

Magana JG, Segura JC 1998: Heritability and factors affecting growth traits and age at first calving of zebu beef heifers in South-Eastern Mexico. Animal Breeding Abstracts 66112.

Mandal A, Sachdeva GK 1999: Genetic analysis of birth weight of calves in cattle. Indian Journal of Animal Sciences 69 979-980.

Martinez RA, Perez IE, Herazo T 2006: Estimation of genetic parameters and variance components for growth traits in Costeno Con Cuernos cattle in Colombian humid tropic. $8^{\text {th }}$ World Congress on Genetics Applied to Livestock Production, Belo Horizonte, Minas Gerais, Brazil, 13-18 August, pp. 32-20. 
Martinez VG, Montano BM, Rivera AD 2002: Genetic parameters for age at first calving and interval beginning of breeding season-calving in purebred Guzerat and Criollo cows and reciprocal crosses, and birth and weaning weight of their calves. Proceedings of the $7^{\text {th }}$ World Congress on Genetics Applied to Livestock Production, Montpellier, France, held in August, pp 0-4.

Martins FR, Biffani S, Lobo RNB, Giorgetti A, Bozzi R 2002: Genetic parameters of growth traits in Nellore cattle reared. $7^{\text {th }}$ World Congress on Genetics Applied to Livestock Production, Montpellier, France, held in August, pp. 1-4.

Padua JT, Silva RG 1996: Estimation of genetic parameters and factors involved in the performance of graded Chianina x Nelore cattle. Animal Breeding Abstracts 64604.

Rabeya T, Bhuiyan AKFH, Habib MA, Hossain MS 2009: Phenotypic and genetic parameters for growth traits in Red Chittagong Cattle of Bangladesh. Journal of Bangladesh Agricultural University 7 265-271.

Rege JEO, Lomole MA, Wakhungu JW 1992: An evaluation of a long-term breeding programme in a closed Sahiwal Herd Kenya. I. Effects of non- genetic factors on performance and genetic parameter estimates. Journal of Animal Breeding and Genetics 109 364-373.

Reynolds WL, Urick JJ, Veseth DA, Kress DD, Nelsen TC, Short RE 1991: Genetic parameters by son-sire (co) variances for growth and carcass traits of Hereford bulls in a non-selected herd. Journal of Animal Science 691000.

Shojo M, Yong Ji Ang, Anada K, Oyama K, Mukai F 2005: Estimation of genetic parameters for growth and feed utilization traits in Japanese Black cattle. Animal Science Journal 76 115-119.

Singh BB, Tyagi JC 1970: Magnitude of effects of factors affecting birth weight of Hariana calves. Indian Veterinary Journal 47 851-854.

Statistical Package for Social Sciences (Version 11.5) 2002: Copyright ${ }^{\odot}$ SPSS Incorporation, 1989-2002. Portion of this product were created using LEADTOOLS ${ }^{\odot}$ 1991-2000, LEAD Technologies Incorporation.

Verma AK, Lohar KS 1985: A genetic study of birth weight of Malvi x Jersey calves. Indian Veterinary Journal $\mathbf{5 4} 279$.

Wakhungu JW, Rage REO, Itilya S 1991: Genetic and phenotypic parameters and trends in production and reproduction performance of Friesian cattle in Kenya. Bulletin of Animal Health and Production in Africa 39 365-372. 